\title{
Burkholderia cocovenenans (van Damme et al. 1960) Gillis et al. 1995 and Burkholderia vandii Urakami et al. 1994 are junior synonyms of Burkholderia gladioli (Severini 1913) Yabuuchi et al. 1993 and Burkholderia plantarii (Azegami et al. 1987) Urakami et al. 1994, respectively
}

\author{
T. Coenye, ${ }^{1}$ B. Holmes, ${ }^{2}$ K. Kersters, ${ }^{1}$ J. R. W. Govan ${ }^{3}$ and P. Vandamme ${ }^{1,4}$
}

Author for correspondence: T. Coenye. Tel: +329264 51 14. Fax: +3292645092. e-mail: Tom.Coenye@rug.ac.be

\footnotetext{
1 Laboratory of Microbiology, Universiteit Gent, K. L. Ledeganckstraat 35, B9000 Ghent, Belgium

2 National Collection of Type Cultures, Central Public Health Laboratory, London NW9 5HT, UK

3 Department of Medical Microbiology, University of Edinburgh, Edinburgh, UK

4 Department of Medical Microbiology, University Hospital UIA, Antwerp, Belgium
}

\begin{abstract}
Reference strains of Burkho/deria cocovenenans and Burkholderia vandii were compared with strains of other Burkholderia species using SDS-PAGE of wholecell proteins, DNA-DNA hybridization and extensive biochemical characterization. Burkholderia gladioli and B. cocovenenans were indistinguishable in the chemotaxonomic and biochemical analyses. Burkholderia plantarii and B. vandii had indistinguishable whole-cell protein patterns but the $B$. vandii type strain differed from $B$. plantarii strains in several biochemical tests. The DNA-DNA binding levels (higher than $70 \%$ ) indicated that (i) B. gladioli and B. cocovenenans, and (ii) B. plantarii and B. vandii each represent a single species. It is concluded that $B$. cocovenenans and $B$. vandif are junior synonyms of B. gladioli and B. plantarii, respectively.
\end{abstract}

Keywords: Burkholderia vandii, Burkholderia cocovenenans, Burkholderia plantarii, Burkholderia gladioli, taxonomy

\section{INTRODUCTION}

The genus Burkholderia is expanding rapidly and presently comprises 14 named species and three unnamed genomovars as described by Vandamme $e t$ al. (1997). In the same study, considerable similarity between (i) Burkholderia cocovenenans and Burkholderia gladioli and (ii) Burkholderia plantarii and Burkholderia vandii was reported (Vandamme et al., 1997).

The organism presently known as $B$. cocovenenans was first described by van Damme et al. (1960) as Pseudomonas cocovenenans, an organism responsible for the production of toxoflavin and bongkrekic acid. Later, it was shown that 'Pseudomonas farinofermentans' strains, isolated from cases of food poisoning caused by the consumption of fermented corn flour, also belonged to $P$. cocovenenans (Zhao et al., 1990). Gillis et al. (1995) showed that $P$. cocovenenans belongs to the Burkholderia rRNA branch, and transferred it to the genus as $B$. cocovenenans. This transfer was later supported by partial 16S rRNA sequence analysis (Zhao et al., 1995). In a polyphasic taxonomic study of Burkholderia strains isolated from cystic fibrosis patients, a striking similarity was observed between the protein patterns from reference strains of $B$. gladioli and $B$. cocovenenans (Vandamme et al., 1997). $B$. gladioli strains are traditionally isolated from Gladiolus spp. and Iris spp., for which B. gladioli is reported to be pathogenic (Palleroni, 1984). B. gladioli has also been cultured from respiratory secretions of cystic fibrosis patients (Christenson et al., 1989).

The name $B$. vandii was proposed by Urakami et al. (1994) for a single plant-associated antibiotic-producing strain. Although the results indicated a close relationship with two other plant-pathogenic species, Burkholderia glumae and $B$. plantarii, $B$. vandii could be distinguished from other members of the genus Burkholderia on the basis of physiological characteristics and DNA-DNA hybridizations.

In the present study, additional strains of $B$. gladioli and $B$. cocovenenans were included in the protein electrophoretic analyses, and quantitative DNADNA hybridizations were performed between the type strains of the different species involved. We also investigated the biochemical characteristics of several representative strains of the different species. 


\section{Table 1. List of Burkholderia strains studied}

ATCC, American Type Culture Collection, Rockville, MD, USA; CCUG, Culture Collection, University of Göteborg, Department of Clinical Bacteriology, Göteborg, Sweden; JCM, Japanese Collection of Microorganisms, Institute of Physical and Chemical Research, Saitama, Japan; LMD, Laboratorium voor Microbiologie, Technische Universiteit, Delft, The Netherlands; LMG, BCCM/LMG Culture Collection Laboratorium voor Microbiologie Gent, Universiteit Gent, Belgium; NCIMB, National Collection of Industrial and Marine Bacteria, Aberdeen, UK; NCPPB, National Collection of Plant-Pathogenic Bacteria, Harpenden Laboratory, Hertfordshire, UK; NCTC, National Collection of Type Cultures, London, UK; PDDCC, Plant Diseases Division Culture Collection, DSIR Mount Albert Research Centre, Auckland, New Zealand.

\begin{tabular}{|c|c|c|c|}
\hline Species & $\begin{array}{c}\text { Strain } \\
\text { designation }\end{array}$ & $\begin{array}{l}\text { Other strain } \\
\text { designation }\end{array}$ & Source \\
\hline B. andropogonis & LMG $2129^{\mathrm{T}}$ & NCPPB 934 & Trifolium repens, leaf spot (USA, 1954) \\
\hline B. caryophylli & LMG $2155^{\mathrm{T}}$ & NCPPB $2151^{\mathrm{T}}$ & Dianthus caryophyllus (USA, 1951) \\
\hline \multirow{3}{*}{ B. cepacia genomovar I } & LMG $1222^{\mathrm{T}}$ & NCTC $10743^{T}$ & Allium сера \\
\hline & LMG 6988 & CCUG 1603 & Leg wound (Sweden, 1972) \\
\hline & LMG 6992 & CCUG 2857 & Soil (Trinidad, 1960) \\
\hline \multirow[t]{3}{*}{ B. cepacia genomovar III } & LMG 13053 & & Cystic fibrosis patient (Belgium, 1987) \\
\hline & LMG 14274 & & Cystic fibrosis patient (Belgium, 1993) \\
\hline & LMG 16661 & & Cystic fibrosis patient (UK) \\
\hline \multirow[t]{3}{*}{ B. cepacia genomovar IV } & LMG 14294 & NCTC 13011 & Cystic fibrosis patient (Belgium, 1993) \\
\hline & LMG 14295 & & Cystic fibrosis patient (Belgium, 1993) \\
\hline & LMG 15949 & & Cystic fibrosis patient (Belgium, 1993) \\
\hline \multirow[t]{2}{*}{ B. cocovenenans } & LMG $11626^{\mathrm{T}}$ & LMD $38.13^{\mathrm{T}}$ & Poisoned bongkrek (Java) \\
\hline & LMG 18113 & NCIMB 12451 & \\
\hline \multirow[t]{7}{*}{ B. gladioli } & LMG $2216^{\mathrm{T}}$ & ATCC $10248^{\mathrm{T}}$ & Gladiolus sp. (USA) \\
\hline & LMG 6881 & NCPPB 1051 & Gladiolus sp. (Zimbabwe) \\
\hline & LMG 6882 & NCPPB 1887 & Gladiolus sp. (USA) \\
\hline & LMG 18157 & $\mathrm{CC} 40$ & Cystic fibrosis patient (USA)* \\
\hline & LMG 18158 & L1 & Cystic fibrosis patient (USA)* \\
\hline & LMG 18159 & OCMH1 & Cystic fibrosis patient (USA)* \\
\hline & LMG 18160 & OCMH2 & Cystic fibrosis patient (USA)* \\
\hline \multirow[t]{2}{*}{ B. glathei } & LMG $14190^{\mathrm{T}}$ & ATCC $29195^{\mathrm{T}}$ & Soil (Germany) \\
\hline & LMG 14932 & ATCC 29198 & Soil (Germany) \\
\hline \multirow[t]{3}{*}{ B. glumae } & LMG 1277 & NCPPB 2391 & Oryza sativa (Japan) \\
\hline & LMG $2196^{\mathrm{T}}$ & NCPPB $2981^{\mathrm{T}}$ & Oryza sativa (Japan) \\
\hline & LMG 6952 & PDDCC 3728 & Oryza sativa (Japan) \\
\hline \multirow[t]{3}{*}{ B. multivorans } & LMG $13010^{\mathrm{T}}$ & NCTC $13007^{\mathrm{T}}$ & Cystic fibrosis patient (Belgium, 1992) \\
\hline & LMG 14275 & & Cystic fibrosis patient (Belgium, 1993) \\
\hline & LMG 14293 & & Cystic fibrosis patient (Belgium, 1993) \\
\hline \multirow[t]{3}{*}{ B. plantarii } & LMG $9035^{\mathrm{T}}$ & ICMP $9424^{\mathrm{T}}$ & Oryza sativa (Japan) \\
\hline & LMG 10907 & ICMP 9425 & Soil (Japan) \\
\hline & LMG 10908 & ICMP 9427 & Oryza sativa (Japan) \\
\hline B. pyrrocinia & LMG $14191^{\mathrm{T}}$ & ATCC $15958^{\mathrm{T}}$ & Soil \\
\hline B. vandii & LMG $16020^{\mathrm{T}}$ & JCM $7957^{\mathrm{T}}$ & Vanda sp. (Japan) \\
\hline \multirow{3}{*}{ B. vietnamiensis } & LMG 6998 & CCUG 7246 & Blood (Sweden, 1978) \\
\hline & LMG $10929^{\mathrm{T}}$ & TVV $75^{\mathrm{T}}$ & Rice rhizosphere (Vietnam) \\
\hline & LMG 16232 & CCUG 31370 & $\begin{array}{l}\text { Human bronchial alveolar lavage } \\
\text { (Sweden) }\end{array}$ \\
\hline
\end{tabular}

* See Christenson et al. (1989).

\section{METHODS}

Strains and culture conditions. The strains used in this study are listed in Table 1. All the strains were routinely grown on Trypticase soy agar (BBL, Becton Dickinson Microbiology Systems) and were incubated in air at $28^{\circ} \mathrm{C}$ or $37^{\circ} \mathrm{C}$.

SDSPAGE of whole-cell proteins. Strains were grown on buffered nutrient agar ( $\mathrm{pH} \mathrm{6.8)}$, containing $0 \cdot 1 \%(\mathrm{w} / \mathrm{v})$ beef extract, $0.2 \%(\mathrm{w} / \mathrm{v})$ yeast extract, $0.5 \%(\mathrm{w} / \mathrm{v}) \mathrm{NaCl}, 0.5 \%$ (w/v) peptone, $0.04 \%$ (w/v) $\mathrm{KH}_{2} \mathrm{PO}_{4}, 0.24 \% \mathrm{Na}_{2} \mathrm{HPO}_{4}$. $12 \mathrm{H}_{2} 0$ and $2.0 \%(\mathrm{w} / \mathrm{v})$ agar, for $48 \mathrm{~h}$ at $28^{\circ} \mathrm{C}$. Preparation of whole-cell proteins and SDS-PAGE was performed as described before (Pot et al., 1994). Densitometric analysis, normalization and interpolation of the protein profiles, and numerical analysis were performed using the GelCompar 4.0 software package (Applied Maths). The correlation coefficient is expressed as percentage similarity for convenience. 
Preparation of high-molecular-weight DNA and DNA-DNA hybridization experiments. Preparation of high-molecularweight DNA for DNA-DNA hybridization experiments and the determination of the degree of DNA-DNA binding by the initial renaturation rate method was performed as described previously (Vandamme et al., 1992; De Ley et al., 1970). Each value given is the mean of at least two hybridization experiments. The total DNA concentration was $65 \mu \mathrm{g} \mathrm{ml}^{-1}$, and the optimal renaturation temperature in $2 \times \operatorname{SSC}(1 \times \mathrm{SSC}$ is $0.15 \mathrm{M} \mathrm{NaCl}$, plus $0.015 \mathrm{M}$ sodium citrate, $\mathrm{pH} 7 \cdot 0$ ) was $80.7^{\circ} \mathrm{C}$.

Biochemical characterization. Biochemical tests were carried out as described previously (Holmes et al., 1975).

\section{RESULTS}

\section{SDSPAGE of whole-cell proteins and DNA-DNA hybridization experiments}

The reproducibility of the SDS-PAGE technique was checked by preparing protein extracts in duplicate. The correlation level between the patterns obtained with different extracts of the same strain was more

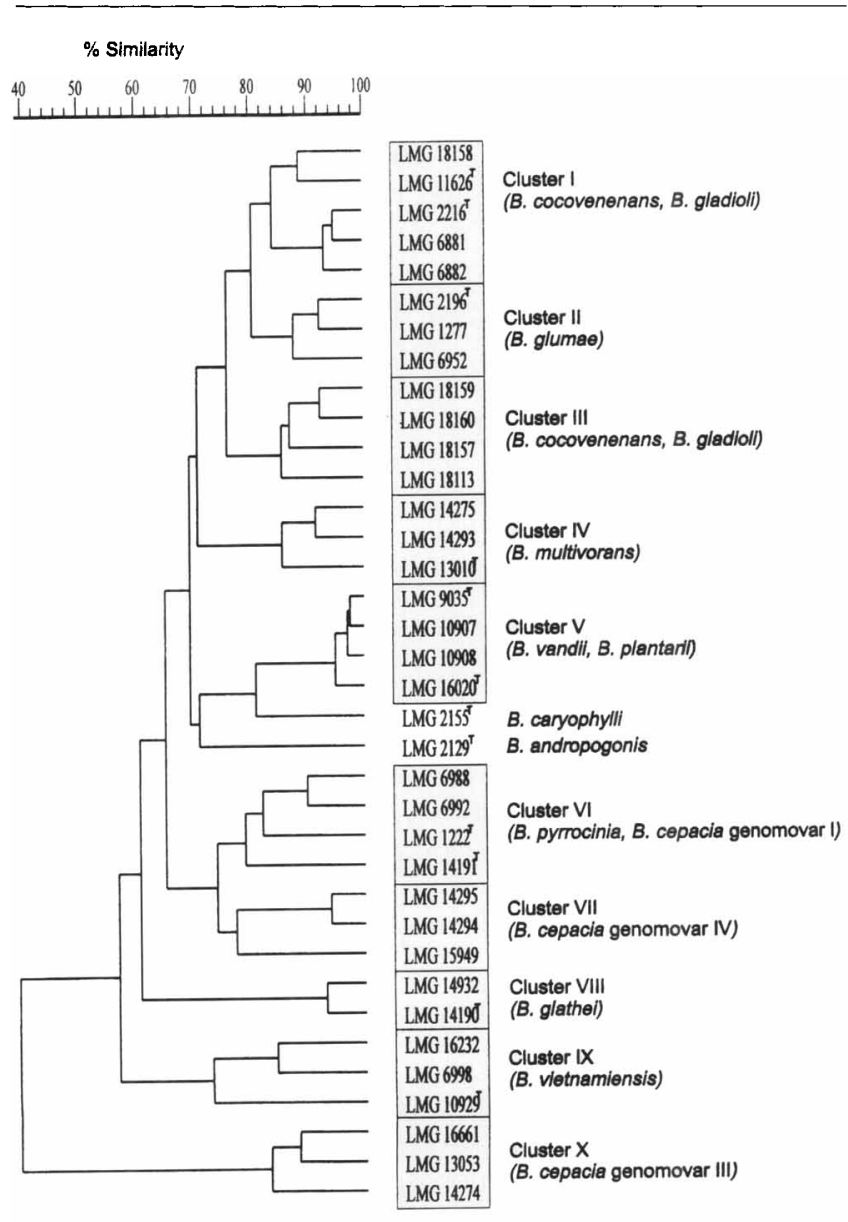

Fig. 1. Dendrogram derived from the unweighted pair group mean linkage of correlation coefficients between the protein patterns of the strains studied. The correlation coefficient is expressed as percentage similarity for convenience. than $93 \%$ (data not shown). After numerical analysis and visual comparison of the profiles, 10 clusters could be delineated, while several strains each occupied a separate position in the dendrogram (Fig. 1). Fig. 2 shows the whole-cell protein profiles of a selection of B. gladioli, B. cocovenenans, B. glumae, B. plantarii and $B$. vandii strains. The results of the DNA-DNA hybridization experiments are shown in Table 2.

\section{Biochemical characteristics}

Biochemical tests were performed on $B$. cocovenenans (strains LMG $11626^{\mathrm{T}}$ and LMG 18113), B. plantarii (strains LMG 9035 , LMG 10907 and LMG 10908), $B$. vandii (strain LMG $16020^{\mathrm{T}}$ ) and $B$. glumae (strains LMG 1277, LMG 2196 ${ }^{\mathrm{T}}$ and LMG 6952). Data on the biochemical characteristics of $B$. gladioli strains are available from a previous study (Vandamme et al., 1997). All strains tested were positive for the following characteristics: motility and growth at room temperature; growth on MacConkey's agar and on $\beta$ hydroxybutyrate; catalase and lecithinase activity; alkali production on Christensen's citrate and growth on Simmons' citrate agar; acid production from ammonium-salt medium with glucose, L-arabinose,

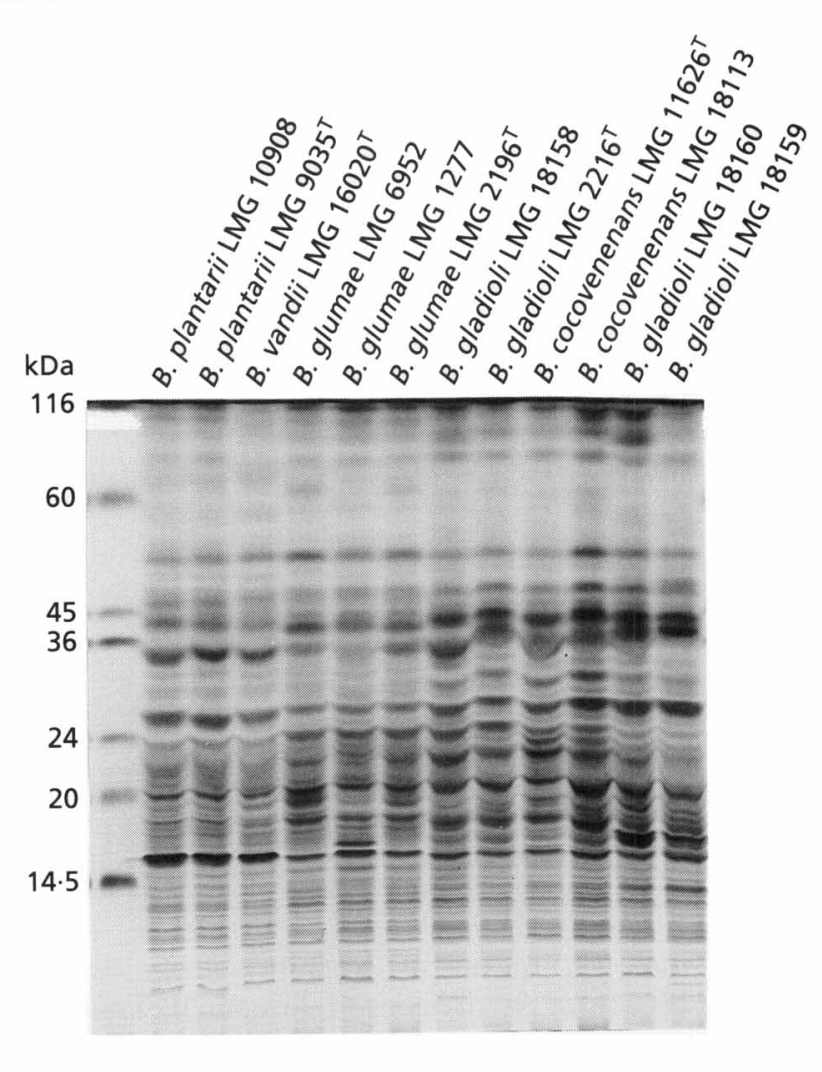

Fig. 2. Electrophoretic protein patterns of a selection of strains investigated. The molecular-mass markers used (left-hand lane) were (from top to bottom) $\beta$-galactosidase, bovine albumin, egg albumin, glyceraldehyde-3-phosphate dehydrogenase, trypsinogen, trypsin inhibitor and lysozyme. 
Table 2. DNA-DNA binding values of all strains examined

\begin{tabular}{|c|c|c|c|c|c|c|c|}
\hline \multirow[t]{2}{*}{ Strain } & \multicolumn{7}{|c|}{$\%$ DNA-DNA binding value with strain } \\
\hline & $\begin{array}{l}\text { LMG } \\
11626^{T}\end{array}$ & $\begin{array}{l}\text { LMG } \\
\text { 2216 }^{\mathrm{T}}\end{array}$ & $\begin{array}{l}\text { LMG } \\
\text { 2196 }^{\mathrm{T}}\end{array}$ & $\begin{array}{l}\text { LMG } \\
\text { 9035 }^{\mathrm{T}}\end{array}$ & $\begin{array}{l}\text { LMG } \\
16020^{T}\end{array}$ & $\begin{array}{l}\text { LMG } \\
\text { 1222 }^{\mathrm{T}}\end{array}$ & $\begin{array}{l}\text { LMG } \\
10929^{T}\end{array}$ \\
\hline B. cocovenenans LMG $11626^{\mathrm{T}}$ & 100 & & & & & & \\
\hline B. gladioli LMG $2216^{\mathrm{T}}$ & 73 & 100 & & & & & \\
\hline B. glumae LMG $2196^{\mathrm{T}}$ & 23 & 0 & 100 & & & & \\
\hline B. plantarii LMG $9035^{\mathrm{T}}$ & 13 & 27 & 59 & 100 & & & \\
\hline B. vandii LMG $16020^{\mathrm{T}}$ & & & & 77 & 100 & & \\
\hline B. cepacia LMG $1222^{\mathrm{T}}$ & 13 & 11 & 38 & 4 & 21 & 100 & \\
\hline B. vietnamiensis LMG $10929^{\mathrm{T}}$ & 31 & & & & 30 & 36 & 100 \\
\hline
\end{tabular}

Table 3. Biochemical tests yielding strain- or taxon-dependent results

Values given are the number of strains showing the character.

\begin{tabular}{|c|c|c|c|c|c|}
\hline Character & $\begin{array}{l}\text { B. gladioli } \\
(n=12)\end{array}$ & $\begin{array}{l}\text { B. cocovenenans } \\
\quad(n=2)\end{array}$ & $\begin{array}{l}\text { B. glumae } \\
(n=3)\end{array}$ & $\begin{array}{c}\text { B. vandii } \\
(n=1)\end{array}$ & $\begin{array}{l}\text { B. plantarii } \\
(n=3)\end{array}$ \\
\hline Growth at $37^{\circ} \mathrm{C}$ & 12 & 2 & 3 & 0 & 0 \\
\hline Growth at $42^{\circ} \mathrm{C}$ & 0 & 2 & 3 & 0 & 0 \\
\hline Growth on cetrimide & 2 & 2 & 3 & 1 & 3 \\
\hline Pigment production & 1 & 0 & 0 & 0 & 0 \\
\hline Pigment production on tyrosine & 1 & 0 & 0 & 0 & 0 \\
\hline Oxidase activity & 12 & 1 & 1 & 1 & 3 \\
\hline Oxidative reaction & 11 & 2 & 3 & 1 & 3 \\
\hline Nitrate reduction & 5 & 2 & 3 & 1 & 3 \\
\hline Urease activity & 9 & 2 & 3 & 0 & 3 \\
\hline Gelatinase production & 10 & 0 & 1 & 1 & 3 \\
\hline Malonate utilization & 0 & 2 & 1 & 1 & 1 \\
\hline$\beta$-Galactosidase activity & 3 & 2 & 3 & 1 & 0 \\
\hline $\begin{array}{l}\text { Acid production from peptone } \\
\text { water and glucose }\end{array}$ & 0 & 0 & 0 & 0 & 3 \\
\hline \multicolumn{6}{|l|}{ Acid production from: } \\
\hline Glucose $(10 \%, \mathrm{w} / \mathrm{v})$ & 10 & 2 & 3 & 1 & 3 \\
\hline Lactose $(10 \%, w / v)$ & 1 & 0 & 0 & 1 & 3 \\
\hline \multicolumn{6}{|c|}{ Acid production in ammonium-salt medium from: } \\
\hline Adonitol & 12 & 1 & 3 & 0 & 0 \\
\hline Cellobiose & 7 & 2 & 3 & 1 & 3 \\
\hline Glycerol & 11 & 2 & 3 & 1 & 0 \\
\hline Raffinose & 0 & 0 & 3 & 0 & 0 \\
\hline Rhamnose & 0 & 0 & 0 & 0 & 3 \\
\hline Salicin & 0 & 1 & 1 & 1 & 0 \\
\hline Casein digestion & 11 & 1 & 0 & 1 & 3 \\
\hline
\end{tabular}

dulcitol, inositol, mannitol, sorbitol, trehalose, Dxylose and fructose; hydrolysis of Tween 20 , Tween 80 and tyrosine; and presence of poly- $\beta$-hydroxybutyrate inclusion granules. All strains tested were negative for the following characteristics: motility at $37^{\circ} \mathrm{C}$; tolerance to $\mathrm{KCN}$; hydrogen sulphide and indole production; gluconate oxidation; phenylpyruvic acid production; arginine, lysine and ornithine decarboxylase activity; gas production from peptone water and glucose; acid production from ammonium-salt medium with lactose and sucrose; growth in the presence of $0.4 \%$ selenite; nitrite reduction; aesculin and starch hydrolysis; fluorescence on King's B medium; growth at $5{ }^{\circ} \mathrm{C}$; and arginine desimidase and DNase activity. Tests in which there were differences among strains are shown in Table 3. 
Reclassification of $B$. cocovenenans and $B$. vandii

\section{DISCUSSION}

Relationship between $B$. cocovenenans and $B$. gladioli

Zhao et al. (1990) allocated the name Pseudomonas cocovenenans for a group of strains isolated from fermented corn flour and reported a DNA-DNA binding value of $96 \%$ between strains NCIB $9450^{\mathrm{T}}$ (LMG 11626 ${ }^{\mathrm{T}}$ ) and NCIMB 12451 (LMG 18113). A mean DNA-DNA binding level of about $58 \%$ was reported towards a $B$. cepacia reference strain; other Burkholderia species were not included in the hybridization assays. $B$. cocovenenans was reported to differ biochemically from other Burkholderia species, including $B$. gladioli, and both species were subsequently transferred to the genus Burkholderia (Yabuuchi et al., 1992; Gillis et al., 1995), which was proposed by Yabuuchi et al. (1992) for the rRNA group II pseudomonads. However, the surprisingly high similarity in whole-cell protein patterns between $B$. gladioli and the type strain of $B$. cocovenenans (Vandamme et al., 1997) prompted us to perform DNA-DNA hybridizations between the type strains of both species and to investigate the biochemical characteristics of other reference strains of both species. The whole-cell protein patterns of the additional $B$. cocovenenans and $B$. gladioli reference strains were highly similar (Fig. 2). However, when subjected to numerical analysis, two separate clusters, each comprising both $B$. cocovenenans and $B$. gladioli strains, were formed. The reason for this is a high-density protein band in the region between 35 and $43 \mathrm{kDa}$, which is present in some strains but absent in others (Fig. 2). When this region was omitted from the numerical analysis, all strains formed a single homogeneous cluster (data not shown) as expected from the high DNA-DNA binding values between the $B$. cocovenenans strains LMG $11626^{\mathrm{T}}$ and LMG 18113 (cluster I and III, respectively) (Zhao et al., 1995) and between the B. gladioli and $B$. cocovenenans type strains (both cluster I) (Table 2). Zhao et al. (1995) reported that $B$. cocovenenans could be distinguished from $B$. gladioli by differences in the utilization of leucine (absent in $B$. cocovenenans strains and present in $B$. gladioli strains) and nicotinate (present in $B$. cocovenenans strains and absent in $B$. gladioli strains). However, the data for the utilization for nicotinate were erroneously cited from Palleroni \& Holmes (1981), where $B$. gladioli was reported to be positive for the utilization of nicotinate. Biochemical tests performed in the present study (Table 3) show that the $B$. gladioli and B. cocovenenans strains differ in the utilization of malonate and the capability of growth at $42^{\circ} \mathrm{C}$. In summary, the DNA-DNA binding level and whole-cell protein pattern similarity indicate that both taxa represent a single species. Differences in the utilization of malonate and leucine, and growth at $42{ }^{\circ} \mathrm{C}$ represent intraspecies variability like several other tests shown in Table 3 . We conclude that $B$. gladioli and $B$. cocovenenans represent the same taxon, with $B$. cocovenenans a junior synonym of $B$. gladioli.

\section{Relationship between B. vandii and B. plantarii}

The name $B$. vandii was proposed by Urakami et al. (1994) for a single strain isolated from Vanda sp. They reported a DNA-DNA binding value of $57 \%$ between $B$. vandii LMG $16020^{\mathrm{T}}$ and the type strain of $B$. plantarii. This value is at the borderline for species separation. In our analyses, we found a DNA-DNA binding value of $77 \%$ between the type strains of the two species, whereas in general our DNA-DNA binding values tend to be lower than those reported by Urakami et al. (1994). We previously reported a high similarity in the whole-cell protein patterns and fatty acid composition of $B$. vandii and $B$. plantarii strains (Vandamme et al., 1997). Biochemically, the B. vandii strain differed in several characteristics from the $B$. plantarii strains examined, as shown in Table 3 . However, the high level of DNA-DNA hybridization, which is in agreement with the protein electrophoretic similarity, in our opinion, outweighs these biochemical differences. These differences reveal the presence of biochemical sub-groups within this species and may warrant the creation of different biotypes or even subspecies within $B$. plantarii. However, we feel that such taxonomic modification should only be proposed when additional strains substantiate the results obtained with strain LMG $16020^{\mathrm{T}}$. We therefore conclude that $B$. vandii and $B$. plantarii represent the same species, and that $B$. vandii should be considered a junior synonym of $B$. plantarii. We do not propose a separate status for strain LMG 16020 within this species until similar isolates become available and can be characterized.

\section{Differentiation of B. glumae, B. gladioli (including B. cocovenenans) and B. plantarii (including $B$. vandii)}

Although the protein patterns of $B$. gladioli and $B$. glumae are similar (Fig. 2), the DNA-DNA binding level between $B$. glumae LMG $2196^{\mathrm{T}}$ and reference strains of $B$. gladioli was not significant (below $25 \%$ ). $B$. glumae can be distinguished from $B$. gladioli by the production of acid from raffinose in ammonium-salt medium (Table 3). Several other biochemical differences have been described by Azegami et al. (1987). Surprisingly, we found a rather high level of DNADNA binding between the $B$. glumae and $B$. plantarii type strains $(59 \%)$. Both taxa have clearly different whole-cell protein patterns (Figs 1 and 2) and can also be distinguished by biochemical characteristics (Zhao et al., 1995). Furthermore, Stead (1992) and Vandamme et al. (1997) reported that both species can be differentiated by cellular fatty acid analyses.

\section{ACKNOWLEDGEMENTS}

T.C. acknowledges the support received from the Vlaams Instituut voor Bevordering van Wetenschappelijk-technologisch onderzoek in de Industrie (Belgium) in the form of a bursary for advanced study. P. V. and K. K. are indebted to the Fund for Scientific Research-Flanders (Belgium) for a 
position as a postdoctoral fellow, and for research and personnel grants, respectively. We acknowledge the financial support received from the Cystic Fibrosis Trust (UK) (grant RS15) and wish to thank Renata Coopman for excellent technical assistance.

\section{REFERENCES}

Azegami, K., Nishiyama, K., Watanabe, Y., Kadota, I., Ohuchi, A. \& Fukazawa, C. (1987). Pseudomonas plantarii sp. nov., the causal agent of rice seedling blight. Int $J$ Syst Bacteriol 37, 144-152.

Christenson, J. C., Welch, D. F., Mukwaya, G., Muszynsky, M. J., Weaver, R. E. \& Brenner, D. J. (1989). Recovery of Pseudomonas gladioli from respiratory tract specimens of patients with cystic fibrosis. J Clin Microbiol 27, 270-273.

van Damme, P. A., Johannes, A. G., Cox, H. C. \& Berends, W. (1960). On toxoflavin, the yellow poison of Pseudomonas cocovenenans. Recl Trav Chim Pays-Bas Belg 79, 255-267.

De Ley, J., Cattoir, H. \& Reynaerts, A. (1970). The quantitative measurement of DNA hybridization from renaturation rates. Eur J Biochem 12, 133-142.

Gillis, M., Van Van, T., Bardin, R. \& 7 other authors (1995). Polyphasic taxonomy in the genus Burkholderia leading to an emended description of the genus and proposition of Burkholderia vietnamiensis sp. nov. for $\mathrm{N}_{2}$-fixing isolates from rice in Vietnam. Int J Syst Bacteriol 45, 274-289.

Holmes, B., Lapage, S.P. \& Malnick, H. (1975). Strains of Pseudomonas putrefaciens from clinical material. J Clin Pathol 28, 149-155.

Palleroni, N. J. (1984). Genus I Pseudomonas Migula 1894, $237^{\mathrm{AL}}$. In Bergey's Manual of Systematic Bacteriology, vol. 1, pp. 141-199. Edited by N. R. Krieg \& J. G. Holt. Baltimore: Williams \& Wilkins.

Palleroni, N. J. \& Holmes, B. (1981). Pseudomonas cepacia, sp. nov., nom. rev. Int J Syst Bacteriol 31, 479-481.
Pot, B., Vandamme, P. \& Kersters, K. (1994). Analysis of electrophoretic whole-organism protein fingerprints. In Chemical Methods in Prokaryotic Systematics, pp.493-521. Edited by M. Goodfellow \& A. G. O'Donnell. Chichester: Wiley

Stead, D. E. (1992). Grouping of plant-pathogenic and some other Pseudomonas spp. by using cellular fatty acid profiles. Int $J$ Syst Bacteriol 42, 281-295.

Urakami, T., Ito-Yoshida, C., Araki, H., Kijima, T., Suzuki, K. \& Komagata, K. (1994). Transfer of Pseudomonas plantarii and Pseudomonas glumae to Burkholderia as Burkholderia spp. and description of Burkholderia vandii sp. nov. Int J Syst Bacteriol 44, 235-245.

Vandamme, P., Vancanneyt, M., Pot, B. \& 10 other authors (1992). Polyphasic taxonomic study of the emended genus Arcobacter with Arcobacter butzleri comb. nov. and Arcobacter skirrowii sp. nov., an aerotolerant bacterium isolated from veterinary specimens. Int J Syst Bacteriol 42, 344-356.

Vandamme, P., Holmes, B., Vancanneyt, M. \& 8 other authors (1997). Occurrence of multiple genomovars of Burkholderia cepacia in cystic fibrosis patients and proposal of Burkholderia multivorans sp. nov. Int J Syst Bacteriol 47, 1188-1200.

Yabuuchi, E., Kosako, Y., Oyaizu, H., Yano, I., Hotta, H., Hashimoto, Y., Ezaki, T. \& Arakawa, M. (1992). Proposal of Burkholderia gen. nov. and transfer of seven species of the Pseudomonas homology group II to the new genus, with the type species Burkholderia cepacia (Palleroni and Holmes 1981) comb. nov. Microbiol Immunol 36, 1251-1275.

Zhao, N.-X., Ma, M.-S., Zhang, Y.-P. \& Xu, D.-C. (1990). Comparative description of Pseudomonas cocovenenans (van Damme, Johannes, Cox, and Berends 1960) NCIB 9450 ${ }^{\mathrm{T}}$ and strains isolated from cases of food poisoning caused by consumption of fermented corn flour in China. Int $J$ Syst Bacteriol 40, 452-455.

Zhao, N.-X., Qu, C., Wang, E. \& Chen, W. (1995). Phylogenetic evidence for the transfer of Pseudomonas cocovenenans (van Damme et al. 1960) to the genus Burkholderia as Burkholderia cocovenenans (van Damme et al. 1960) comb. nov. Int J Syst Bacteriol 45, 600-603. 